
$(N S N)$

\title{
In vitro Inhibitory Effects of Cyperus esculentus L. (Tiger Nut) Tubers on some Enzymes Associated with Neurodegeneration and Iron- Induced Lipid Peroxidation in Rats' Brain Tissue Homogenate
}

\author{
Ayodeji A. Olabiyi ${ }^{1}$ \\ ${ }^{1}$ Department of Medical Biochemistry, Afe Babalola University, Ado Ekiti, Nigeria
}

Received:

August 2020

Accepted:

October 2020

\begin{abstract}
This study investigated the inhibitory effect of Cyperus esculentus L. (raw and processed) tubers on Iron $\left(\mathrm{Fe}^{2+}\right)$ induced lipid peroxidation and key enzymes linked with neurodegeneration in vitro. Ten grams of tiger nut tubers was weighed and added to $100 \mathrm{~mL}$ of distilled water $(1: 10 \mathrm{w} / \mathrm{v})$, left for $24 \mathrm{~h}$, filtered, centrifuged to obtain a clear supernatant and lyophilized. Activities of acetyl cholinesterase (AChE), butyryl cholinesterase (BChE), $\mathrm{Fe}^{2+}$-induced lipid peroxidation as well as antioxidants status as indicated by 2,2-azino-bis (3-ethylbenthiazoline-6-sulphonic acid radical scavenging ability and $\mathrm{Fe}$ chelation were evaluated. Raw tiger nut extracts inhibited activities of AChE and BChE in the brain tissue of rats $(0-11.54 \mathrm{mg} / \mathrm{mL})$ with $E_{50}=3.599 \mathrm{mg} / \mathrm{mL}$ and $2.71 \pm 0.01 \mathrm{mg} / \mathrm{mL}$ respectively, and increased antioxidant activity when compared with the processed tuber. Inhibition on these enzymes as well as prevention of $\mathrm{Fe}^{2+}$ induced lipid peroxidation may be the possible mechanism of action by which tiger nut prevents neurodegeneration.
\end{abstract}

Key words: Tiger nut; Acetyl cholinesterase; Butyryl cholinesterase; Neuroprotection; Antioxidant

\section{INTRODUCTION}

In recent years, studies have implicated oxidative stress role in neurodegenerative disease such as Alzheimer's disease (AD), via lipid peroxidation of cell membranes of neurons (Pratico and Delanty 2000; Saliu et al. 2017). Of particular importance, the brain is an organ extremely susceptible to free radical damage because of its high oxygen demands and its relatively low concentration of antioxidant enzymes and free radical scavengers (Kaul and Forman 2000). $A D$ was first described by the German neurologist Alois Alzheimer, as a neurodegenerative disease affecting the brain which was an irreversible, progressive brain disease that slowly destroys memory and thinking skills and eventually leading to inability to carry out simple task (Cumming and Cole 2002) such as, finding the right words for a situation, vision/spatial issues and impaired reasoning. The human brain is one of the most metabolically active organs in the body and metabolizes a large amount of glucose to produce cellular energy in the form of adenosine triphosphate (ATP) (Cunnane et al. 2011). If the brain is unable to produce ATP, synapses cannot be maintained and cells cannot function, ultimately leading to impaired cognition (Costantini et al. 2008).

Cholinergic deficit has been well documented in $A D$ and therefore, cholinesterase enzyme family has become imperative in neuropathology of $A D$, as acetylcholinesterase (AChE) and butyrylcholinesterase (BChE) hydrolyze the neurotransmitters; acetylcholine and butyrylcholine respectively (Giacobini 1998). AChE is the primary cholinesterase in the body, hydrolyzing the neurotransmitter acetylcholine and other choline esters at the neuromuscular junctions and brain cholinergic synapses, thus, terminating signal transmission. AChE exists in multiple molecular forms which

Correspondence: Ayodeji A. Olabiyi, PhD, Department of Medical Biochemistry, Afe Babalola University, PMB 5454, Ado Ekiti, Nigeria. Email: olabiyiaa@abuad.edu.ng, Phone: $+2348060715060$ 
possess similar catalytic properties, but differ in their oligomeric assembly and mode of cell attachment to the cell surface. The major form of AChE is found in the brain, muscle and other tissues in the hydrophilic species, which forms disulphide linked oligomers with collagenous, or lipid containing structural subunits. Alzheimer's medications work to preserve acetylcholine by inhibiting AChE. BChE produced by the liver, circulates in the blood is involved in the breakdown of certain drugs, including muscle relaxants called choline esters used during general anaesthesia. BChE also breaks down toxic substances before they reach the nerves and is found in significantly higher quantities in $A D$ plaques than in plaques of age related non demented brains (Schneider 2001).

Tiger nut is valued for it's highly nutritious starch content, dietary fibre and digestible carbohydrate (Oladele et al. 2009), and has been cultivated as a livestock feed and for human consumption. It can be eaten raw, roasted, grated, baked or used for ice cream and beverage amongst others (Belewu and Abodunrin 2006; Sanful 2009). For many years, tiger nut tubers have been considered to have adequate properties to fight respiratory infections and some stomach illnesses (Belewu and Abodunrin 2006). Tiger nut is known to be very rich in phytochemicals and has been an important ingredient in folklore medicine for the treatment/management of $A D$ with limited scientific basis. This study therefore seeks to assess its effect on the key enzymes (AChE and $B C h E$ ) linked with $A D$ as well as $\mathrm{Fe}^{2+}$-induced lipid peroxidation.

\section{MATERIALS AND METHODS}

\section{Materials \\ Sample Collection}

Tiger nut (Cyperus esculentus L.) was purchased June 2016 from a local market in Akure, Nigeria. The nuts were thoroughly washed under running tap to remove stones and other dirt. Thereafter, a portion of the nuts was roasted in an electric oven for $30 \mathrm{~min}$ at $120{ }^{\circ} \mathrm{C}$. The remaining portion was oven dried at 45 ${ }^{\circ} \mathrm{C}$ to a constant weight, and the two samples were pulverized, milled, defatted in cold $n$-hexane and kept prior to analysis. A voucher specimen of the nut was deposited at the Federal University of Technology, Akure Centre for Research and Development (CERAD) herbarium.

\section{Aqueous Extract Preparation}

Ten grams $(10 \mathrm{~g})$ each of the milled samples were subjected to aqueous extraction at room temperature of $25{ }^{\circ} \mathrm{C}$ for $24 \mathrm{~h}$ in $100 \mathrm{~mL}$ of distilled water $(1: 10$ $w / v)$. The mixture was filtered, centrifuged (model $\mathrm{KX} 3400 \mathrm{C}$ ) to obtain clear supernatant which was then freeze-dried (Lab-Kit FD-10-MR model; Lab-
Kits, Utherm International, China) and stored in the refrigerator for subsequent analysis (Oboh et al. 2007).

\section{Chemicals and Reagents}

Thiobarbituric acid (TBA), 1,10-phenanthroline, deoxyribose, gallic acid, Folin-Ciocalteau's reagent were obtained from Sigma-Aldrich, Inc., (St Louis, $\mathrm{MO}$ ), trichloroacetic acid (TCA) was sourced from Sigma-Aldrich, Chemie $\mathrm{GmbH}$ (Steinheim, Germany), dinitrophenyl hydrazine (DNPH) from ACROS Organics (New Jersey, USA), hydrogen peroxide, nhexane, methanol, acetic acid, thiourea, copper (II) tetrasulphate (VI) pentahydrate $\left(\mathrm{CuSO}_{4} .5 \mathrm{H}_{2} \mathrm{O}\right)$, sulphuric acid $\left(\mathrm{H}_{2} \mathrm{SO}_{4}\right)$, sodium carbonate, aluminium trichloride $\left(\mathrm{AlCl}_{3}\right)$, potassium acetate, Tris-HCl buffer, sodium dodecyl sulphate, Iron (II) tetrasulphate (VI) $\left(\mathrm{FeSO}_{4}\right)$, potassium ferricyanide and ferric chloride were sourced from BDH Chemicals Ltd., (Poole, England) while the water was glass distilled.

\section{Methods \\ Determination of Total Phenol Content}

The total phenol content was determined according to the method of Singleton et al. (1999). Briefly, appropriate dilutions of tiger nut extracts (raw and processed) were oxidized with $0.5 \mathrm{~mL}(500 \mu \mathrm{L}) 10 \%$ Folin-Ciocalteau's reagent $(\mathrm{v} / \mathrm{v})$ and neutralized by $0.4 \mathrm{~mL}(400 \mu \mathrm{L})$ of $7.5 \%$ sodium carbonate. The reaction mixture was incubated for $40 \mathrm{~min}$ at $45{ }^{\circ} \mathrm{C}$ and the absorbance was measured at $765 \mathrm{~nm}$ in the JENWAY UV-visible spectrophotometer. The total phenol content was subsequently calculated as gallic acid equivalent.

$\left(\mathrm{Abs}_{\mathrm{ref}}-\mathrm{Abs}_{\mathrm{sample}}\right) / \mathrm{Abs}_{\mathrm{ref}} \times 100-$ Formula 1 where $A b_{\text {ref }}=$ absorbance of the reference (reacting mixture without the test sample) and $\mathrm{Abs}_{\text {sample }}=$ absorbance of reacting mixture with the test sample.

\section{Determination of Total Flavonoid Content}

The total flavonoid content was determined using a slightly modified method reported by Meda et al. (2005). Briefly $0.5 \mathrm{~mL}$ of tiger nut tuber aqueous extract was mixed with $0.5 \mathrm{~mL}$ methanol, $50 \mu \mathrm{L} 10 \%$ $\mathrm{AlCl}_{3}, 50 \mu \mathrm{L} 1 \mathrm{M}$ potassium acetate and $1.4 \mathrm{~mL}$ water, and allowed to incubate at room temperature for 30 min. The absorbance of the reaction mixture was subsequently measured at $415 \mathrm{~nm}$ in the JENWAY UV-visible spectrophotometer; the total flavonoid content was calculated with quercetin as standard using equation 1 .

\section{Determination of Vitamin C (Ascorbic Acid)}

Vitamin $\mathrm{C}$ content of the tiger nuts (raw and processed) was determined using the method of Benderitter et al. (1998). Briefly, $75 \mu \mathrm{L}$ DNPH (2 g dinitrophenyl hydrazine, $230 \mathrm{mg}$ thiourea and $270 \mathrm{mg}$ $\mathrm{CuSO}_{4} .5 \mathrm{H}_{2} \mathrm{O}$ in $100 \mathrm{~mL}$ of $5 \mathrm{M} \mathrm{H}_{2} \mathrm{SO}_{4}$ ) were added to $500 \mu \mathrm{L}$ reaction mixture [300 $\mu \mathrm{L}$ of the extracts with 
$100 \mu \mathrm{L} 13.3 \% \mathrm{TCA}$ and $100 \mu \mathrm{L}$ water]. The reaction mixture was subsequently incubated for $3 \mathrm{~h}$ at $37{ }^{\circ} \mathrm{C}$, then $0.5 \mathrm{~mL}(500 \mu \mathrm{L})$ of $65 \% \mathrm{H}_{2} \mathrm{SO}_{4}(\mathrm{v} / \mathrm{v})$ was added to the medium and the absorbance was measured at $520 \mathrm{~nm}$ in the UV-visible spectrophotometer. The vitamin $\mathrm{C}$ content of the raw and processed tiger nut was subsequently calculated using ascorbic acid as standard.

\section{In vitro Antioxidant Studies}

2,2'-azino-bis (3-ethylbenzthiazoline-6-sulphonic acid) (ABTS) Radical Scavenging Ability

The ABTS radical scavenging ability' (ABTS*) scavenging ability of the extracts were determined according to the method described by $\mathrm{Re}$ et al. (1999). The ABTS* was generated by reacting an ABTS aqueous solution $(7 \mathrm{mmol} / \mathrm{L})$ with potassium persulphate $\left(\mathrm{K}_{2} \mathrm{~S}_{2} \mathrm{O}_{8}\right) \quad(2.45 \mathrm{mmol} / \mathrm{L}$, final concentration) in the dark for $16 \mathrm{~h}$ and adjusting the Abs734 $\mathrm{nm}$ to 0.700 with ethanol. Tiger nut extract $(0.2 \mathrm{~mL})$ was added to $2.0 \mathrm{~mL}$ ABTS* solution and the absorbance were measured at $734 \mathrm{~nm}$ after 15 min in the UV-visible spectrophotometer. The trolox equivalent antioxidant capacity (TEAC) was subsequently calculated.

\section{Iron $\left(\mathrm{Fe}^{2+)}\right.$ Chelation Ability}

The $\mathrm{Fe}^{2+}$ chelating ability of the tiger nut extracts were determined using the method of Puntel et al. (2005). Freshly prepared $500 \mu \mathrm{M} \mathrm{FeSO} 4(150 \mu \mathrm{L})$ was added to a reaction mixture containing $168 \mu \mathrm{L}$ $0.1 \mathrm{M}$ Tris- $\mathrm{HCl}(\mathrm{pH} 7.4), 218 \mu \mathrm{L}$ saline and the extracts $(20,40,60$ and $80 \mu \mathrm{L})$. The reaction mixture was incubated for $15 \mathrm{~min}$ at room temperature, before the addition of $13 \mu \mathrm{L} \quad 0.25 \% \quad 1$, 10 phenanthroline (w/v). The absorbance was subsequently measured at $510 \mathrm{~nm}$ in the UV-visible spectrophotometer.

Table 1: Total Phenolics, Total Flavonoid and Vitamin C Contents of Aqueous Extracts of Cyperus esculentus $\mathbf{L}$.

\begin{tabular}{llll}
\hline Samples & $\begin{array}{l}\text { Total } \\
\text { phenolics } \\
(\mathrm{mg} / \mathrm{g})\end{array}$ & $\begin{array}{l}\text { Total } \\
\text { flavonoid } \\
(\mathrm{mg} / \mathrm{g})\end{array}$ & $\begin{array}{l}\text { Vitamin C } \\
(\mathrm{mg} / \mathrm{g})\end{array}$ \\
\hline TIG 1 & $2.00 \pm 0.14^{\mathrm{a}}$ & $0.32 \pm 0.12^{\mathrm{a}}$ & $1.040 \pm 0.100^{\mathrm{b}}$ \\
TIG 2 & $2.72 \pm 0.15^{\mathrm{b}}$ & $0.47 \pm 0.03^{\mathrm{b}}$ & $0.97 \pm 0.035^{\mathrm{a}}$ \\
\hline
\end{tabular}

Values represent mean \pm standard deviation of triplicate readings. Values with the same superscript letter along the same column are not significantly different $(P>0.05)$. TIG 1- processed tiger nut; TIG 2 - raw tiger nut

\section{Fenton Reaction (Degradation of Deoxyribose)}

The method of Halliwell and Gutteridge (1981) was used to determine the ability of the extract to prevent $\mathrm{Fe}^{2+} / \mathrm{H}_{2} \mathrm{O}_{2}$ induced decomposition of deoxyribose. The extract ranging between $0-100 \mu \mathrm{L}$ was added to a reaction mixture containing $120 \mu \mathrm{L}$ of $20 \mathrm{mM}$ deoxyribose, $400 \mu \mathrm{L}$ of $0.1 \mathrm{M}$ phosphate buffer, $40 \mu \mathrm{L}$ of $500 \mu \mathrm{M}$ of $\mathrm{FeSO}_{4}$, and the volume were made up to $800 \mu \mathrm{L}$ with distilled water. The reaction mixture was incubated at $37{ }^{\circ} \mathrm{C}$ for $30 \mathrm{~min}$ and the reaction was then stopped by the addition of $0.5 \mathrm{~mL}$ of $2.8 \%$ trichloroacetic acid. This was followed by addition of $0.4 \mathrm{~mL}$ of $0.6 \%$ TBA solution. The test tubes containing the reaction mixtures were subsequently incubated in boiling water for $20 \mathrm{~min}$. The absorbance was measured at $532 \mathrm{~nm}$ in the JENWAY UV-Visible spectrophotometer.

\section{Determination of Ferric Reducing Antioxidant Property}

The reducing property of the tiger nut extracts was determined by assessing their ability to reduce iron (III) chloride $\left(\mathrm{FeCl}_{3}\right)$ solution as described by Oyaizu (1986). Exactly $2.5 \mathrm{~mL}$ aliquot was mixed with $2.5 \mathrm{~mL}$ $200 \mathrm{mM}$ sodium phosphate buffer $(\mathrm{pH} \mathrm{6.6)}$ and 2.5 $\mathrm{mL} 1 \%$ potassium ferricyanide. The mixture was incubated at $50{ }^{\circ} \mathrm{C}$ for $20 \mathrm{~min}$, and then $2.5 \mathrm{~mL} 10 \%$ TCA was added. This mixture was centrifuged at 650 rpm for $10 \mathrm{~min}$. About $5 \mathrm{~mL}$ of the supernatant was mixed with an equal volume of water and $1 \mathrm{~mL} 0.1 \%$ ferric chloride. The absorbance was measured at 700 $\mathrm{nm}$ in the UV-visible spectrophotometer.

\section{Lipid Peroxidation Assay}

Animals and Preparation of Tissue Homogenates

Wistar rats $(n=8)$ were obtained and house at the Afe Babalola University animal house $\left(25^{\circ} \mathrm{C}\right)$, fed with standard feed and given water ad libitum. The use of the animals was approved by Afe Babalola Ethical Committee with the reference number ABUAD/EC/2017/202. The rats were decapitated under mild diethyl ether anaesthesia and the brains rapidly isolated, placed on ice and weighed. The tissue was subsequently homogenized in cold saline $(1 / 10 \mathrm{w} / \mathrm{v})$ with about 10-up-and-down strokes at approximately $1200 \mathrm{rev} / \mathrm{min}$ in a Teflon glass homogenizer. The homogenates were centrifuged for $10 \mathrm{~min}$ at $3000 \mathrm{xg}$ to yield pellets that were discarded, and a low-speed supernatant (S1) was kept for lipid peroxidation assay (Belle et al. 2004).

\section{Lipid Peroxidation and Thiobarbibutric Acid Reactions}

The lipid peroxidation assay was carried out using the modified method of Ohkawa et al. (1979). Briefly, $100 \mu \mathrm{L} \mathrm{S1}$ fraction was mixed with a reaction mixture containing $30 \mu \mathrm{L}$ of $0.1 \mathrm{M}$ at $\mathrm{pH} 7.4$ Tris- $\mathrm{HCl}$ buffer, extract $(0-100 \mu \mathrm{L})$ and $30 \mu \mathrm{L}$ of $250 \mu \mathrm{M}$ freshly prepared $\mathrm{FeSO}_{4}$. The volume was made up to $300 \mu \mathrm{L}$ by water before incubation at $37{ }^{\circ} \mathrm{C}$ for $2 \mathrm{~h}$. The colour reaction was developed by adding $300 \mu \mathrm{L}$ $8.1 \%$ sodium dodecyl sulphate to the reaction mixture containing $\mathrm{S} 1$. This was subsequently followed by the addition of $500 \mu \mathrm{L}$ of acetic acid/ $\mathrm{HCl}(\mathrm{pH} 3.4)$ mixture and $500 \mu \mathrm{L} 0.8 \%$ TBA. This mixture was incubated at $100{ }^{\circ} \mathrm{C}$ for $1 \mathrm{~h}$. Thiobarbituric acid reactive species 
(TBARS) produced were measured at $532 \mathrm{~nm}$ in the UV-visible spectrophotometer and the absorbance was compared with that of standard curve using malondialdehyde (MDA).

\section{Cholinesterase Inhibition Assay}

Cholinesterase inhibition was assessed by a modified colorimetric method (Ellman et al. 1961). The AChE and $\mathrm{BChE}$ activities were determined in a reaction mixture containing $200 \mu \mathrm{L}$ of a solution of $5,5^{\prime}$ dithiobis 2-nitrobenzoic acid (DTNB) (3.3 mM in 0.1 $\mathrm{M}$ phosphate-buffered solution, $\mathrm{pH}$ 7.0) containing sodium hydrogen carbonate $\left(\mathrm{NaHCO}_{3}\right) \quad(6 \mathrm{mM})$, aqueous extracts of tiger nut (raw and processed) and $500 \mu \mathrm{L}$ of phosphate buffer $(\mathrm{pH} 8.0)$. After incubation for $20 \mathrm{~min}$ at $25{ }^{\circ} \mathrm{C}, 100 \mu \mathrm{L}$ of $0.05 \mathrm{mM}$ acetylthio-choline iodide and butyrylthio-choline iodide solution were added as the substrates for AChE and BChE respectively, and their activities were determined as changes in absorbance reading at $412 \mathrm{~nm}$ for $3 \mathrm{~min}$ at $25^{\circ} \mathrm{C}$ in a spectrophotometer. The inhibitory activities were expressed as percentage inhibition using the equation 1.

\section{Statistical Analysis}

The results of the three replicates were pooled and expressed as mean \pm standard deviation (Zar 1984). One way analysis of variance was used to analyse the results and Duncan multiple test was used as post hoc test.

Table 2: ABTS Radical Scavenging Ability and Ferric Reducing Antioxidant Properties of Cyperus esculentus L. Aqueous Extracts

\begin{tabular}{lll}
\hline Samples & $\begin{array}{l}\text { ABTS } \\
(\mathrm{mmol} . T E A C / g)\end{array}$ & $\begin{array}{l}\text { FRAP } \\
(\mathrm{mg} . \mathrm{GAE} / 100 \mathrm{~g})\end{array}$ \\
\hline TIG 1 & $462.560 \pm 330.400^{\mathrm{a}}$ & $0.70 \pm 0.10^{\mathrm{a}}$ \\
TIG 2 & $1079.305 \pm 770.935^{\mathrm{b}}$ & $1.30 \pm 0.10^{\mathrm{b}}$ \\
\hline
\end{tabular}

Values represent mean \pm standard deviation of triplicate readings. Values with the same superscript letter along the same column are not significantly different $(P>0.05)$. TIG 1- processed tiger nut; TIG 2 - raw tiger nut; FRAP ferric reducing antioxidant properties

\section{RESULTS}

The results revealed total phenolic content of the raw tiger nut $(2.715 \mathrm{mg} / \mathrm{g})$ and that of the processed tiger nut $(2.00 \mathrm{mg} / \mathrm{g})$. The total flavonoid content in same manner showed raw tiger nut $(0.470 \mathrm{mg} / \mathrm{g})$ higher than processed tiger nut $(0.320 \mathrm{mg} / \mathrm{g})$. The ascorbic acid (vitamin $\mathrm{C}$ ) content of raw and processed tiger nut showed $1.04 \mathrm{mg} / \mathrm{g}$ and $0.97 \mathrm{mg} / \mathrm{g}$, respectively (Table 1).

The ABTS scavenging ability is presented as trolox equivalent antioxidant capacity (mmol.TEAC/100g). The results showed that both extracts scavenged
ABTS radical; however, the raw sample (1079.305 mmol.TEAC/g) had a significantly higher ABTS scavenging ability compared to the processed sample $(462.560 \mathrm{mmol} . \mathrm{TEAC} / \mathrm{g})$. Ferric reducing antioxidant properties of the aqueous extract of the tiger nut showed that the raw sample aqueous extract (1.3 mg.GAE $/ 100 \mathrm{~g}$ ) had a higher reducing power than the processed $(0.7 \mathrm{mg}$.GAE $/ 100 \mathrm{~g}$ ) (Table 2).

The hydroxyl radical $\left(\mathrm{OH}^{-}\right)$scavenging ability of the aqueous extracts of tiger nut showed that all the extracts were able to scavenge $\mathrm{OH}^{*}$ produced from the decomposition of deoxyribose in fenton reaction (Fig. 1). Furthermore, the tiger nut extracts chelated $\mathrm{Fe}^{2+}$ considering their $\mathrm{EC}_{50}$ (concentration of extracts required to inhibit $50 \%$ of activity) value for raw (4.22 $\pm 0.01 \mathrm{mg} / \mathrm{mL}$ ) and processed $(4.81 \pm 0.04 \mathrm{mg} / \mathrm{mL})$ tiger nut extract (Fig. 2; Table 3). The incubation of rats' brain tissue in the presence of $250 \mu \mathrm{M} \mathrm{FeSO}_{4}$ caused a significant increase in the MDA content of the brain (Fig. 3). However, the introduction of the tiger nut extracts inhibited MDA production in a dose dependent manner $(0-33.33 \mathrm{mg} / \mathrm{mL})$.

Both extracts inhibited AChE activity. However, raw tiger nut extract $\left(\mathrm{EC}_{50}=3.599 \pm 0.03 \mathrm{mg} / \mathrm{mL}\right)$ had a higher AChE inhibitory activity than the processed tiger nut extract $\left(E_{50}=7.000 \pm 0.08 \mathrm{mg} / \mathrm{mL}\right)$ (Fig. 4; Table 4). Both extracts also inhibited BChE activity in vitro. Nevertheless, the raw tiger nut extract $\left(\mathrm{EC}_{50}=\right.$ $2.71 \pm 0.01 \mathrm{mg} / \mathrm{mL}$ ) had higher BChE inhibitory activity than the processed tiger nut extract $\left(\mathrm{EC}_{50}=\right.$ $4.76 \pm 0.03 \mathrm{mg} / \mathrm{mL}$ ) (Fig. 5; Table 4).

\section{DISCUSSION}

Cyperus esculentus L. tubers have long been recognized for their health benefits as they have high content of soluble glucose, rich in minerals for bone, tissue repairs, muscle and blood stream. They are also found to be rich in antioxidant vitamins (vitamin $\mathrm{E}$ and $\mathrm{C}$ ) and vitamin B1 which assist in balancing the central nervous system by providing support and encourage the body to adapt to stress (Belewu and Abodunin 2006; Sanful 2009).

Free radicals have an important role in pathogenesis of a wide range of disease including AD. Phenolic compounds can protect the body from free radicals, whose formation is associated with the normal metabolism of aerobic cells. Flavonoids are widely found in food products derived from plant source and they have been shown to possess significant antioxidant activities that could lower cellular oxidative stress and act as a natural radical scavenger (Oboh et al. 2007; 2013). Ascorbic acid is a good reducing agent and exhibit antioxidant activities by electron donation. It helps the immune system to fight off foreign invaders and tumour cells, and supports the cardiovascular system by facilitating fat metabolism and protecting tissue from free 
radicals damage, while also assisting the nervous system convert certain amino acids to neurotransmitters. The ascorbic acid content of raw and processed tiger nut $(1.04 \pm 0.01 \mathrm{mg} / \mathrm{g}$ and $0.97 \pm 0.035 \mathrm{mg} / \mathrm{g})$ from our study was lower than that reported for Solanum anguivi Lam fruits (Elekofehinti and Kade 2012).

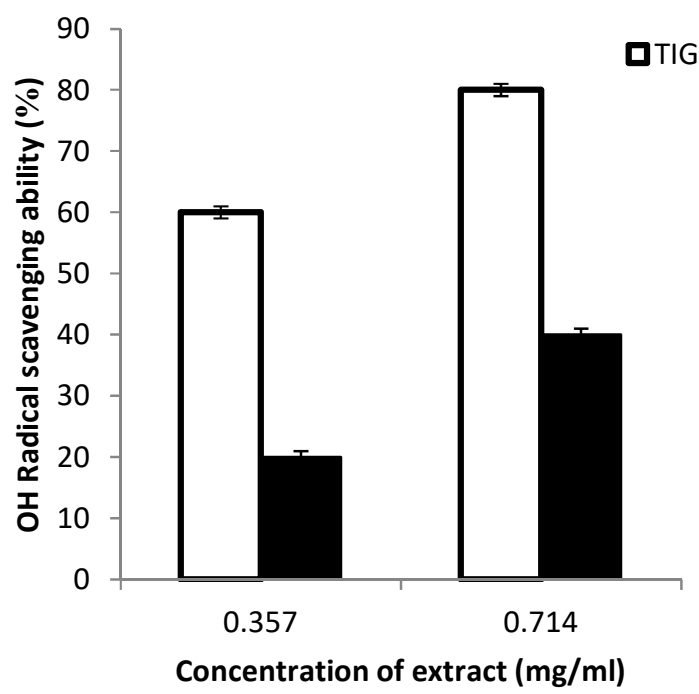

Fig. 1: $\mathrm{OH}^{*}$ radical scavenging ability of aqueous Cyperus esculentus L. extracts.. $\mathrm{OH}^{-}$- hydroxyl radical; TIG 1- processed tiger nut; TIG 2 - raw tiger nut

Antioxidant can prevent biological and chemical substances from free radical-induced oxidative damage and stress. Consequently, antioxidants have gained a great attention for their potential in management of many diseases (Zhang-Numes et al. 2006). Since deregulation of metal ions such as $\mathrm{Fe}^{2+}$, $\mathrm{Cu}^{2+}$ and $\mathrm{Zn}^{2+}$ and consequential induction of oxidative stress have been reported to be associated with AD (Matinez (2003), antioxidant mechanism demonstrated by the tiger nut (raw and processed) could play some part in the prevention of oxidativestress-induced neurodegeneration. Iron $\left(\mathrm{Fe}^{2+}\right)$ chelating ability may also be one of the possible mechanisms through which antioxidants phytochemicals in tiger nut extract prevents lipid peroxidation in tissues by forming a complex with $\mathrm{Fe}$, thus preventing the initiation of lipid peroxidation (Oboh et al. 2007).

The incubation of rat brain tissues in the presence of $250 \mu \mathrm{M} \mathrm{FeSO}_{4}$ caused a significant increase in the MDA content of the brain (185.7\%). This finding agrees with the report of Butterfield and Lauderback (2002), where significant increase in MDA production was observed in the presence of $\mathrm{Fe}^{2+}$. The MDA in the presence of $\mathrm{Fe}^{2+}$ could be attributed to the fact that $\mathrm{Fe}^{2+}$ can catalyze one-electron transfer reactions that generate reactive oxygen species, such as the reactive $\mathrm{OH}^{*}$, which is formed from $\mathrm{H}_{2} \mathrm{O}_{2}$ through the Fenton reaction (Zago et al. 2000). Elevated $\mathrm{Fe}^{2+}$ content in the brain have been linked to a host of neurodegenerative disease which include $A D$, a finding demonstrated in animal models of disease by Matinez (2003). However, the introduction of the tiger nut extracts inhibited MDA production in a dose dependent manner $(0-33.33 \mathrm{mg} / \mathrm{mL})$ and this finding is consistent with the report of Butterfield and Lauderback (2002), where plant extracts inhibited $\mathrm{Fe}^{2+}$-induced lipid peroxidation in rat brain in vitro. The tiger nut tuber extracts probably had a high inhibitory effect on $\mathrm{Fe}^{2+}$-induced lipid peroxidation in brain tissue probably due to its high phenolic, flavonoid and vitamin C contents. It could be speculated that tiger nut, being a good iron chelator must have prevented the oxidation of iron (II), thereby preventing the generation of hydroxyl radical and inhibiting oxidative stress in the process.

Acetylcholine (Ach) is one of the neurotransmitters in the autonomic nervous system. It acts on both the peripheral and central nervous systems, and is the only neurotransmitter used in the motor division of the somatic nervous system. In the central nervous system, acetylcholine and the associated neurons from the cholinergic system, tends to cause antiexcitatory actions. ACh has an important role in enhancing sensory perception when one wakes up (Jones 2005) and in sustaining attention (Himmelheber et al. 2000). AChE is an important regulatory enzyme that controls the transmission of nerve impulses across cholinergic synapses by hydrolysing the excitatory transmitter acetylcholine (ACh) (Milatovic and Dettburn 1996). Normally, in the healthy brain $A C h E$ is predominant, however, in $A D$ brain BChE activity rises while AChE activity remains unchanged or diminished (Gray et al. 1987). Inhibition of AChE is considered as a promising

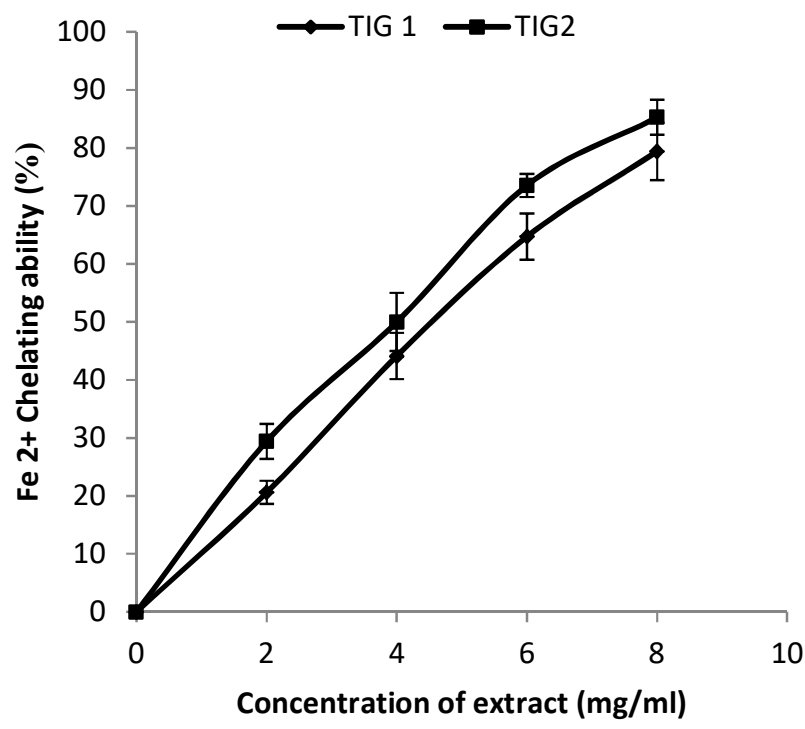

Fig. 2: Iron chelating ability of aqueous of Cyperus esculentus L. extracts. TIG 1- processed tiger nut; TIG 2 - raw tiger nut 
approach for the treatment of AD (Quinn 1987). $\mathrm{BChE}$ on the other hand has been considered to be directly associated with the side effects of the AChE inhibitors and the existing drugs of $A D$ (Tong et al. 1996). More recent studies have shown that BChE is found in significantly quantities in $A D$ plaques than in plaques of age related non-demented brains. Aqueous extract of Cyperus esculentus L. inhibited both AChE and BChE. The inhibition of these cholinesterases could be as a result of important phytochemicals in these extracts. Phenolic acids such as caffeic acid, chlorogenic acids and catechin have been reported to be a potent inhibitor of AChE and BChE (Anwar et al. 2012; Oboh et al. 2013). Therefore, inhibition of both AChE and BChE by the tiger nut extracts is an indication that the nut could have potential therapeutic benefits. However, the processed tiger nut extract showed a reduced effect on the antioxidant and key enzymes inhibitory abilities compared to the raw extract.

Table 3: $\mathrm{EC}_{50}$ of Aqueous Cyperus esculentus L. Extracts on $\mathrm{Fe}^{2+}$ Chelating Ability and Inhibition of $\mathrm{Fe}^{2+}$ - induced Lipid Peroxidation in Rats' Brain

\begin{tabular}{lll}
\hline Samples & $\begin{array}{l}\mathrm{EC}_{50} \text { of } \mathrm{Fe}^{2+} \text { chelating } \\
\text { ability }(\mathrm{mg} / \mathrm{mL})\end{array}$ & $\begin{array}{l}\mathrm{EC}_{50} \text { of } \mathrm{Fe}^{2+} \text { induced } \\
\text { lipid peroxidation } \\
(\mathrm{mg} / \mathrm{mL})\end{array}$ \\
\hline TIG 1 & $4.81 \pm 0.04^{\mathrm{b}}$ & $25.78 \pm 1.2^{\mathrm{b}}$ \\
TIG 2 & $4.22 \pm 0.01^{\mathrm{a}}$ & $20.19 \pm 0.9 \mathrm{a}$ \\
\hline
\end{tabular}

Values with the same superscript letter along the same column are not significantly different $(P>0.05)$. $\mathrm{EC}_{50}-$ concentration of extracts required to inhibit $50 \%$ of activity; TIG 1- processed tiger nut; TIG 2 - raw tiger nut

\section{Conclusion}

The aqueous extract of tiger nut (Cyperus esculentus L.) from our findings showed significant anticholinesterase properties as well as antioxidant activity. The nut extracts were also able to protect the brain homogenates from $\mathrm{Fe}^{2+}$ induced lipid peroxidation in vitro. Hence, the tiger nut has potential usefulness as functional food in the management of neurodegenerative disease such as Alzheimer's disease as it exhibited inhibitory activity on key enzymes (AChE and BChE) linked to this disease.

\section{Conflict of Interest}

None declared

\section{REFERENCES}

Anwar, M.A., Ford, W.R., Broadley, K.J. and Herbert A.A. (2012) Vasoconstriction and vasodilator responses to tryptamine of rat isolated perfused mesentery, comparison with tyramine and $\beta$ phenylethylamine. British Journal of Pharmacology. 165(7):2191-2202.

Belewu, M.A. and Abodunrin, O.A. (2006) Preparation of kunnu from unexploited rich food source: tiger nut (Cyperus esculentus). World Journal of Dairy and Food Science. (1):19-21.

Belle, N.A.V., Dalmolin, G.D., Fonini, G., Rubim, M.A and Rocha, J.B.T. (2004) Polyamines reduces lipid peroxidation induced by different pro-oxidant agents. Brain Research. 1008:245-251.

Benderitter, M., Maupoil, V., Vergely, C., Dalloz, F., Briot, F. and Ochette, L. (1998) Studies by electron paramagnetic resonance of the importance of iron in hydroxyl scavenging properties of ascorbic acid in plasma: effects of iron chelators. Fundamental and Clinical Pharmacology. 12:510-516.

Butterfield, D.A. and Lauderback, C.M. (2002) Lipid peroxidation and protein oxidation in Alzheimer's disease brain, potential cause and consequences involving amyloid $\beta$ - peptide-associated free radical oxidative stress. Free Radical Biology and Medicine. 32(11):1050-1060.

Costantini, L.C., Barr, L.J, Vogel, J.L. and Handerson, S.T. (2008) Hypometabolism as a therapeutic target in Alzheimer's disease. BMC Neuroscience. (9):516.

Cumming, J.L. and Cole, G. (2002) Alzheimer disease. Journal of American Medical Association. 287(18):2335-2338.

Table 4: EC50 of Aqueous Cyperus esculentus L. Extracts on AChE and BChE in Rats' Brain

\begin{tabular}{lll}
\hline Samples & $\begin{array}{l}\mathrm{EC}_{50} \text { of } \mathrm{AChE} \\
(\mathrm{mg} / \mathrm{mL})\end{array}$ & $\begin{array}{l}\mathrm{EC}_{50} \text { of } \mathrm{Fe}^{2+} \mathrm{BChE} \\
(\mathrm{mg} / \mathrm{mL})\end{array}$ \\
\hline TIG 1 & $7.000 \pm 0.08^{\mathrm{b}}$ & $4.76 \pm 0.03^{\mathrm{b}}$ \\
TIG 2 & $3.599 \pm 0.03^{\mathrm{a}}$ & $2.71 \pm 0.01^{\mathrm{a}}$
\end{tabular}

Values with the same superscript letter along the same column are not significantly different $(p>0.05)$. AChE acetylcholinesterase; BChE - butyrylcholinesterase; $E_{50}$ - concentration of extracts required to inhibit $50 \%$ of activity; TIG 1- processed tiger nut; TIG 2 - raw tiger nut

Cunnane, S., Nugent, S. and Roy, M. (2011) Brain fuel metabolism, aging and Alzheimer's disease. Nutrition. 27(1):3-30

Elekofehinti, O.O. and Kade, I.J. (2012) Aqueous extract of African egg plant inhibit $\mathrm{Fe}^{2+}$ and SNP induced lipid peroxidation in rat's brain in vitro. Der Pharmacia Lettre. 4(5):1352-1359.

Ellman, G.L., Courtney, K.D., Andres, V. and Featherstone, R.M. (1961) A new and rapid colorimetric determination of acetylcholinesterase activity. Biochemistry and Pharmacology. 7:88-95. Giacobini, E. (1998) Cholinesterase inhibitors for Alzheimer's disease therapy from tacrine to future 
applications. Neurochemistry International. 32:413419.

Gray, E.G., Paula-Barbosa, M. and Roher, A. (1987) Alzheimer's disease: paired helical filaments and cytomembranes. Neuropathology and Applied Neurobiology. 13(2):91-110.

Halliwell, B. and Gutteridge, J.M.C. (1981) Formation of a thiobarbituric-acid- reactive substance from deoxyribose in the presence of iron salts: The role of superoxide and hydroxyl radicals. FEBS letters. 128: 347-352.

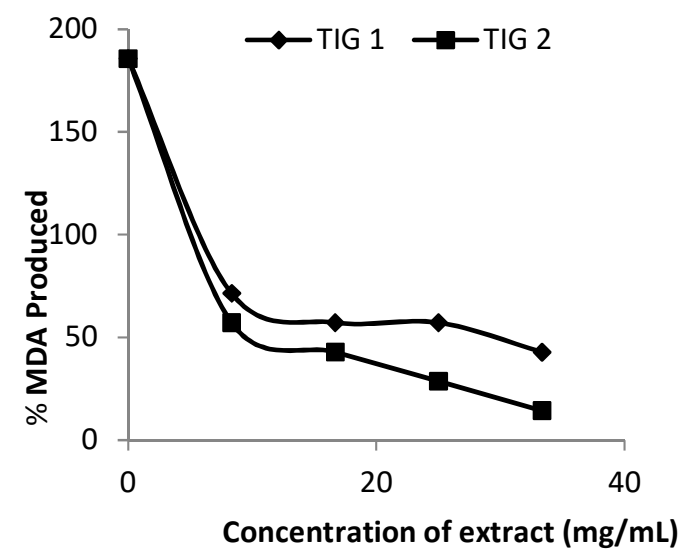

Fig. 3: Iron-induced lipid peroxidation in rat's brain by aqueous Cyperus esculentus L. extracts. TIG 1processed tiger nut; TIG 2 - raw tiger nut

Himmelheber, A.M., Sarter, M., Bruno, J.P. (2000) Increase in cortical acetylcholine release during sustained attention performance in rats. Brain Research. 9(3):313-325.

Kaul, N. and Forman, H.J. (2000) Reactive Oxygen Specie in Physiology and Toxicology: From Lipid Peroxidation to Transcriptional Activation. Rhodes, C.R. (ed). Taylor and Francis; New York: pp 310-335. Jones, B.E. (2005) From waking to sleeping: Neuronal and chemical substrates. Trends in Pharmacological Sciences. 26(11):578-586.

Matinez, G.R., Loureiro, A.P.M. and Marques, S.A. (2003) Oxidative and alkylating damage in DNA. Mutation Research. 544(2-3):115-127.

Meda, A., Lamien, E., Romito, M., Millogo, J. and Nacoulma, O.G. (2005) Determination of the total phenolic, flavonoid and proline contents in Burkina Faso honey, as well as their radical scavenging activity. Food Chemistry. 91:571-577.

Milatovic, D. and Dettburn, W.D. (1996) Modification of acetylcholinesterase during adaptation to chronic, subacute paraoxon application in rat. Toxicology and Applied Pharmacology.136(1):20-28.

Oboh, G., Puntel, R.L. and Rocha, J.B.T. (2007) Hot pepper (Capsium annum, Tepin and Capsicum Chinese, Habenero) prevents $\mathrm{Fe}^{2+}$ induced lipid peroxidation in brain in vitro. Biological Research 102(1):178-185.
Oboh, G., Agunloye, O.M., Akinyemi, A.J., Ademiluyi, A.O. and Adefegha, S.A. (2013) Comparative study on the inhibitory effect of caffeic and chlorogenic acids on key enzymes linked to Alzheimer's disease and some pro-oxidant induced oxidative stress in rats brain- in vitro. Neurochemical Research. 38(2):413419.

Ohkawa, H., Ohishi, N. and Yagi, K. (1979). Assay for lipid peroxides in animal tissues by thiobarbituric acid reaction. Analytical Biochemistry. 95:351-358.

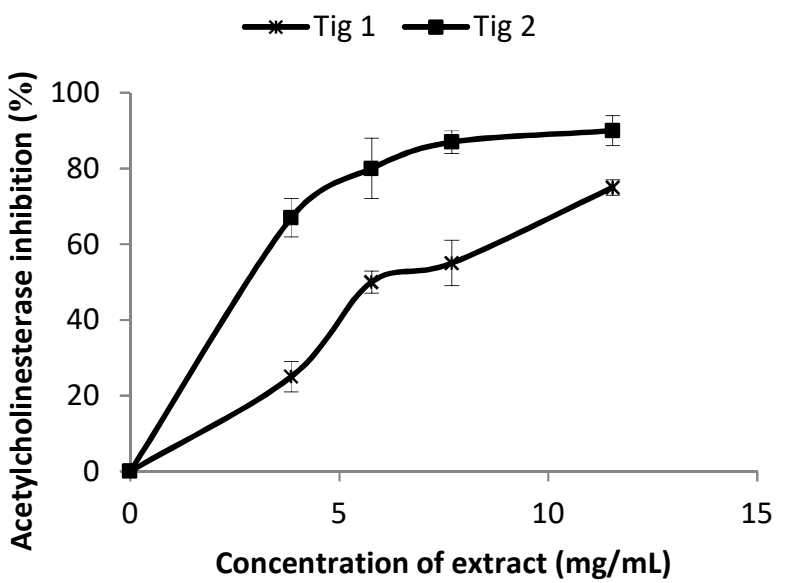

Fig. 4: Acetylcholinesterase activity of aqueous Cyperus esculentus L. extracts. TIG 1- processed tiger nut; TIG 2 - raw tiger nut

Oladele, K.A., Osundahunsi, F.O. and Adebowale, A.Y. (2009) Influence of processing techniques on the nutrients and anti-nutrient of tiger nut (cyperus esculentus). World Journal of Dairy and Food Sciences. 2:88-93.

Oyaizu, M. (1986) Studies on products of browning reaction: antioxidative activity of products of browning

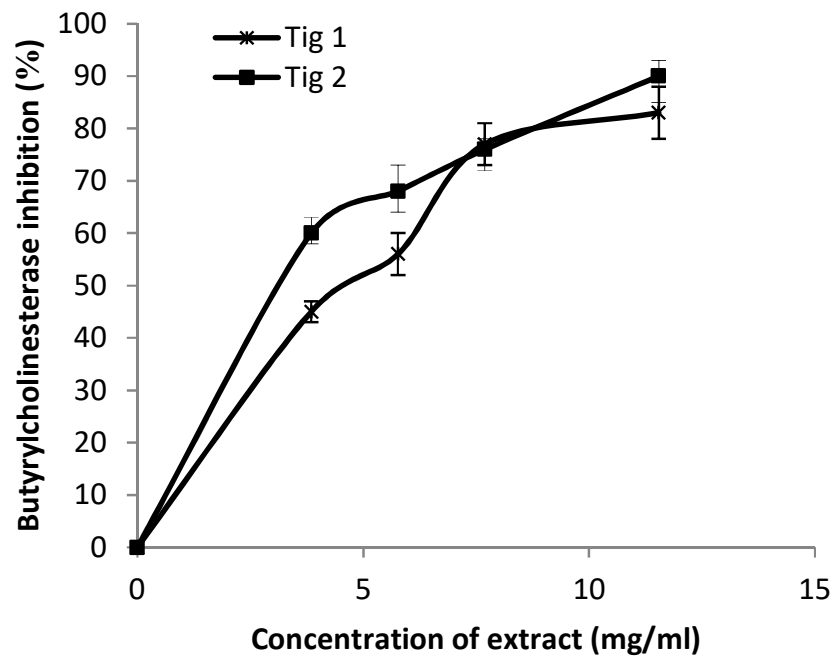

Fig. 5: Butyrylcholinesterase activity of aqueous Cyperus esculentus L. extracts. TIG 1-processed tiger nut; TIG 2 - raw tiger nut 
reaction prepared from glucosamine. Japan Journal of Nutrition. 44:307-315.

Pratico, D. and Delanty, N. (2000) Oxidative injury in disease of the central nervous system: focus on Alzheimer's disease. American Journal of Medicine 109(7):577-585.

Puntel, R.L., Nogueira, C.W. and Rocha, J.B.T. (2005) Krebs cycle intermediates modulate thiobarbituric reactive species (TBARS) production in rat brain In vitro. Neurochemical Research. 30:225235.

Quinn, D.M. (1987) Acetylcholinesterase; enzyme structure, reaction dynamics and virtual transition states. Chemical Reviews. 87(5):955-979.

Re, R., Pellegrini, N., Proteggente, A., Pannala, A., Yang, M. and Rice-Evans, C. (1999) Antioxidant activity applying an improved ABTS radical cation decolorisation assay. Free Radicals in Biology and Medicine. 26:1231-1237.

Saliu, J.A. and Olabiyi, A.A. (2017) Aqueous extract of Securidaca longipendunculata Oliv. and Olax subscropioidea inhibits key enzymes (acetylcholine sterase and butyrylcholinesterase) linked with Alzheimer's disease in vitro, Pharmaceutical Biology. 55(1):252-257.

Sanful, R.E. (2009) The use of tiger nut (Cyperus esculentus), cow milk and their composite as substrates for yoghurt production. Pakistan Journal of Nutrition. 6:755-758.

Schneider, L.S. (2001) Treatment of Alzheimer's disease with cholinesterase inhibitors. Clinics in Geriatic Medicine. 17(2):337-358.

Singleton, V.L., Orthofer, R. and Lamuela-Raventos, R.M. (1999) Analysis of total phenols and other oxidation substrates and antioxidants by means of Folin-Ciocalteau'sreagent. Methods in Enzymology. 299:152-178.

Tong, W., Collantes, E.R., Chen, Y. and Welsh, W.J. (1996) A comparative molecular field analysis study in $\mathrm{N}$-benzylpiperidines as acetylcholinesterase inhibitors. Journal of Medical Chemistry. 39(2):380387.

Zhang-Nune, S.S.X., Maat-Schieman, M.L.C., Vanduinin, S.C., Roos, R.A.C., Frosh, M.P. and Greenbery, S.M. (2006) The cerebral beta-amyloid angiopathies hereditary and sporadiac. Brain Pathology. 16(1):30-39.

Zago, M.P., Verstraeten, S.V. and Oteiza, P.I. (2000) Zinc in the prevention of $\mathrm{Fe}^{2+}$ initiated lipid and protein oxidation. Biological Research. 33(2):143150.

Zar, J.H. (1984) Biostatistical Analysis. Englewood Cliffs: Prentice-Hall Inc: p. 620

Cite as Olabiyi, A.A. (2020) In vitro inhibitory effects of Cyperus esculentus L. (tiger nut) tubers on some enzymes associated with neurodegeneration and $\mathrm{Fe}^{2+}$ - induced lipid peroxidation in rats' brain tissue homogenate. Nig. $\mathrm{J}$. Neurosci. 11(2):81-87. http://doi.org/10.47081/njn2020.11.2/004 